\title{
Article
}

\section{Predicting Effects of Personality Traits, Self-esteem, Language Class Risk-taking and Sociability on Chinese University EFL Learners' Performance in English}

\author{
Liu, Meihua
}

Available at http://clok.uclan.ac.uk/3318/

Liu, Meihua (2012) Predicting Effects of Personality Traits, Self-esteem, Language Class Risk-taking and Sociability on Chinese University EFL Learners' Performance in English. Journal of Second Language Teaching and Research, 1 (1). pp. 30-57. ISSN 2045-4031

It is advisable to refer to the publisher's version if you intend to cite from the work.

For more information about UCLan's research in this area go to http://www.uclan.ac.uk/researchgroups/ and search for <name of research Group>.

For information about Research generally at UCLan please go to http://www.uclan.ac.uk/research/

All outputs in CLoK are protected by Intellectual Property Rights law, including Copyright law. Copyright, IPR and Moral Rights for the works on this site are retained by the individual authors and/or other copyright owners. Terms and conditions for use of this material are defined in the policies page.

\section{CLoK}

Central Lancashire online Knowledge www.clok.uclan.ac.uk

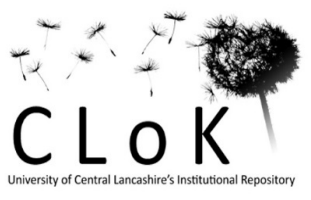


PREDICTING EFFECTS OF PERSONALITY TRAITS, SELF-ESTEEM, LANGUAGE CLASS RISK-TAKING AND SOCIABILITY ON CHINESE UNIVERSITY EFL LEARNERS' PERFORMANCE IN ENGLISH

Meihua Liu, Tsinghua University, China

\begin{abstract}
Although the interactive effects of different variables in language learning have increasingly become the focus of recent research, the interaction of such variables as personality traits, self-esteem, language class risk-taking and sociability has not been much investigated. Hence, the present study explored the predicting effects of these variables on Chinese EFL learners' performance in English at the tertiary level. A 68-item survey involving 934 firstyear undergraduate non-English majors revealed that: (1) the majority were moderately extroverted, moderately inclined to anxiety and fears, and moderately prone to be influenced by social desirability but tended to be dependent and gentle; the participants were moderately satisfied with themselves and believed they were good and worthy; and the majority were moderately risk-taking and sociable in English class, (2) personality traits, selfesteem, language class risk-taking and sociability were generally significantly correlated with one another and with the students' performance in English, and (3) overall self-esteem, language class risk-taking, language class sociability, and two personality variables $-P$ (psychoticism) and L (lie) proved to be powerful predictors for the students' performance in English. As such, personality traits, self-esteem, language class risk-taking and sociability are important factors affecting language learning outcomes.
\end{abstract}

Keywords: personality, self-esteem, risk-taking, sociability, performance 


\section{Introduction}

It is widely noticed that students may attain differing levels of achievement in second or foreign language (SL/FL) learning, even in the same learning situation. In order to understand this phenomenon, researchers have explored numerous factors that may affect language learning with focus on cognitive (e.g. language aptitude, cognitive ability, strategy use), affective (e.g. anxiety, motivation, self-confidence), personality (extroversion, locus of control), and/or demographic (e.g. age, gender) variables (Brown, 1987; Ehrman \& Oxford, 1990, 1995; Gardner, Tremblay, \& Masgoret, 1997; Zhang \& Liu, 2008). Even so, as Gardner et al. (1997) state, there is a lack of research that concurrently examines the relationships between all these variables. This study is an attempt to better understand the relationship between the variables as they apply to a group of Chinese university-level EFL students.

Employing statistical procedures to analyze data, the present study aims to investigate the predicting effects of personality traits, self-esteem, and language class risk-taking and sociability on Chinese university EFL learners' performance in English. For this purpose, the present research recruited first-year undergraduate non-English majors from three EFL contexts in China.

\section{Literature review}

\section{Personality traits}

Since people with varying personality traits perceive the world and interpret it in different ways, they may respond to the same situation differently. Thus, personality traits make a difference in how people learn and what they learn (McCaulley \& Natter, 1974; Myres \& Myres, 1980).

Among the hundreds of personality tests which have been developed for medical, educational and occupational purposes, two tests have been commonly used by researchers in the field of language learning and teaching: the Myers-Briggs Type Indicator (MBTI) and the Eysenck Personality Questionnaire (EPQ). 
Journal of Second Language Teaching and Research Volume One Issue One

Developed in 1975, the 100-item Eysenck Personality Questionnaire (Eysenck \& Eysenck, 1975 ) was later reduced to include 48 items and has been used in various educational settings (Eysenck, 1974; Eysenck \& Eysenck, 1979; Kiany, 1997). It measures three dimensions of a person's personality: extroversion (E), neuroticism (N) (or emotionality), and psychoticism (P) (or tough-mindedness). Apart from these, it has a lie scale $(\mathrm{L})$ to measure the extent to which respondents are influenced by social desirability in answering the questionnaire. An individual who scores high on extroversion (HE) is oriented towards the external world, while an individual who is low on extroversion (LE) is withdrawn and more concerned with inner states of mind; an individual who is high on neuroticism $(\mathrm{HN})$ is more inclined to anxiety and fears; and a person with a low score on neuroticism (LN) is psychologically well-balanced (or stable). Psychoticism $(P)$ is a dimension that can be exhibited by people belonging to all these four types at varying degrees. A person who is high on the psychoticism scale is relatively tough-minded, aggressive and cold, whereas, a person with a low score on the P scale tends to be dependent and tender-minded.

Tender-minded rationalists tend toward principles, intellectualism, idealism, optimism, religiousness, free will, monism and dogmatism, while tough-minded empiricists tend toward facts, sensationalism, materialism, pessimism, irreligiousness, fatalism, pluralism and skepticism. ... The tough think of the tender as sentimentalists and soft-heads while the tender feel the tough to be unrefined, callous, or brutal. (James, 1907, cited in Foust, 2007, p. 12).The role of personality in language learning has long been noted and explored (Brown, 1987; Busch, 1982; Cameron, 1990; Carrell, Prince, \& Astika, 1996; Ehrman \& Oxford, 1990; Hurd, 2006; Hwu, 2007; MacIntyre \& Charos, 1996; Riding \& Banner, 1986; Robinson, Gabriel, \& Katchan, 1994; Verhoeven \& Vermeer, 2002; Wakamoto, 2000). The studies have revealed that certain personality variables such as extroversion, assertiveness, emotional stability, and conscientiousness are conducive to second language learning. For example, Robinson et al.'s (1994) study showed that individuals with high neuroticism (N) and extroversion $(\mathrm{HN} / \mathrm{HE})$ scores did better on the oral tests than on the written tests when compared with participants with high neuroticism and low extroversion scores (HN/LE). Nevertheless, some research fails to support this finding (Busch, 1982; Wilson \& Lynn, 1990 ) and some suggests that introverts are not necessarily disadvantaged (Ehrman \& Oxford, 1990). For example, Ehrman and Oxford (1990) found that introverts did as well as extroverts in language learning. Thus, the reasons for the mixed findings may be that the studies have used different instruments to measure personality characteristics with a heterogeneous or a small group of learners and/or that the researchers investigated different 
aspects of language learning. The findings might be more consistent with a larger and homogeneous sample.

\section{Self-esteem}

Self-esteem refers to 'the evaluation a person makes and customarily maintains with regard to him- or herself' (Coopersmith, 1981, p. 5). It denotes an attitude of approval or disapproval towards oneself and implies the extent to which one believes him/herself capable, significant, successful and useful. This attitude also carries 'positive and negative affective connotations and is intertwined with intellectual and motivational processes' (Coopersmith, 1981, p. 5).

A favorable attitude towards oneself has been considered to be important by several personality theorists as well as psychologists (Coopersmith, 1981; Rogers \& Dymond, 1954). They found that people who frequently seek psychological help often report suffering from feelings of inadequacy and see themselves as helpless and inferior, as incapable of improving their situations, and as lacking the inner resources to tolerate or to reduce the anxiety readily aroused by everyday events and stress. People whose performance does not match their personal aspirations evaluate themselves as inferior no matter how great their achievements. People with high self-esteem are more creative, and more likely to assume an active role in social groups and to express their views frequently and effectively. Students with greater self-esteem are more likely to be successful academically in school (DalgasPelish, 2006; Ja, Huai, \& Guo, 2007; Pepi, Faria, \& Alesi, 2006; Rayle, Arredondo, \& Kurpius, 2005; Stringer \& Heath, 2008), happier (Zhang, 2005), less anxious (Situ \& Li, 2007; Wray \& Stone, 2005), and to adopt higher quality learning strategies (Watkins, 2000).

\section{Language class risk-taking and sociability}

The classroom is a critical place for student interpersonal and educational development (Pierce, 1994). As Krupa-Kwiatkowski (1998, p.133) claimed, 'interaction involves participation, personal engagement, and the taking of initiative in some way, activities that in turn are hypothesized to trigger cognitive processes conducive to language learning'. Since oral participation is the most observable behavior, much research has focused on it and its 
Journal of Second Language Teaching and Research Volume One Issue One

relationship with students' English proficiency or performance (Ely, 1986; Liu \& Jackson, 2008; Spada, 1986; Swain, 1985; Tsou, 2005).

Though many second/foreign language (SL/FL) learners, especially Asian language learners reported a desire to be active and independent learners and to be involved in interpersonal interactions in the target language (Liu \& Jackson, 2011; Littlewood, 2000), in numerous SL/FL learning situations, learners, especially Asian learners, have been observed to be quiet in language classrooms, rarely responding to teachers' questions, or actively taking part in classroom interactions (Jackson, 2001, 2002; Liu, 2006; Saito \& Ebsworth, 2004; Tsui, 1996; Zou, 2004). These behaviors are frequently interpreted by teachers and researchers as a lack of motivation, cultural differences, low proficiency in target language, pursuit of perfection, peer pressure, fear of losing face, habit, lack of confidence, and so on (Cortazzi \& Jin, 1996; Flowerdew, Miller, \& Li, 2000; Jackson, 2002; Liu, 2006; Zou, 2004). Meanwhile, it has been found in some research that the more proficient students tend to be more active in classroom communication (Liu \& Jackson, 2009), that passive participation in classroom activities negatively affects the students' performance in English, especially oral English (Ely, 1986; Liu, 2006), and that students' actual participation is closely related to a series of variables such as willingness to communicate, motivation, anxiety, self-esteem, self-confidence, and global personality traits (Baker \& Maclntyre, 2000; Hashimoto, 2002; Maclntyre \& Charos, 1996; Maclntyre, Baker, Clément, \& Donovan, 2003; Yashima, 2002; Yashima, Zenuk-Nishide, \& Shimizu, 2004).

As Skehan (1989) claims, various factors affect the learning of English, such as self-esteem, language aptitude, motivation, and personality traits. Though much research has been done to explore the interactions of different variables and their effects on the outcome of SL/FL learning, the variables investigated in individual studies are limited and many have not been included here. Moreover, as reviewed above, personality traits, self-esteem, and language class risk-taking and sociability have all proved to be influential factors in language learning, yet they have rarely been researched simultaneously in the same SL/FL learning situation. This, coupled with the fact that mixed findings were uncovered in existing studies, is exactly why more research is required in this area. Situated in Chinese EFL contexts, the present research attempts to investigate the interrelationships of personality traits, self-esteem, 
language class risk-taking and sociability, and their predicting effects on English language learning. To achieve the purpose, the following research questions were formulated:

(1) What are the profiles of Chinese university students' personality traits, self-esteem, and language class risk-taking and sociability?

(2) How are the students' personality traits, self-esteem, language class risk-taking and sociability related to one another?

(3) How far do the variables impact on the students' performance in English?

\section{Research design}

\section{Participants}

The participants were 934 (587 male and 347 female) randomly chosen first-year nonEnglish majors from various disciplines such as Law, Engineering, Mechanics, and Economics and Management at three Chinese universities representing three different ranks of state-owned universities (top-rank, intermediate-rank, and low-rank, which had 366, 323 and 245 participants respectively for the present study). All the students were enrolled in credit-bearing and compulsory English courses offered by their universities. With an age range from 13 (only one student who did exceptionally well in his studies) to 21 and an average age of 18.49 , the majority $(451 / 48.3 \%)$ of the participants were aged 18 , followed by the group aged 19 (315/33.7\%), and then came the group aged $20(97 / 10.4 \%)$ and 17 $(53 / 5.7 \%)$.

\section{Instruments}

For this study, students completed the 48-item Eysenck Personality Questionnaire, the 10item Rosenberg Self-Esteem Scale, the 6-item Language Class Risk-Taking Scale, the 4item Language Class Sociability Scale, and the background questionnaire, as detailed below. 
The Eysenck Personality Questionnaire (EPQ). The 48-item Eysenck Personality Questionnaire was used in the present study because this revised form proved to be more valid and reliable than the original 100-item EPQ (Eysenck, Eysenck, \& Barrett, 1985) and because it was easier to execute. It aimed to measure four dimensions of students' personality, with 12 items for each dimension. For this scale, each item had two descriptors - 'No' and 'Yes' with values of 1 to 2 assigned to them respectively. Thus, each dimension has a possible score range of 12 to 24 (see Appendix 21-68).

The Rosenberg Self Esteem Scale (RSES). This 10-item self-esteem scale, developed by Rosenberg (1965) to measure overall feelings of self-worth or self-acceptance, has been widely used in numerous studies on self-esteem (Dalgas-Pelish, 2006; Pepi et al., 2006; Rayle et al., 2005; Stringer \& Heath, 2008). It includes two dimensions - positive self-esteem (PSE) and negative self-esteem (NSE), with five items for each. The items are answered on a 4-point Likert scale ranging from 'Strongly Agree' to 'Strongly Disagree' with values of 1 to 4 assigned to them respectively, and thus the RSES has a possible score range of 10 to 40 (see Appendix 11-20).

Language Class Risk-Taking Scale (LCR). The LCR scale, a 6-item measure developed by Ely (1986) taps the extent to which learners take risks using the target language in class. Learners who risk using the target language more often are reportedly more willing to communicate with others in class. To fit the English classrooms in Mainland China, the word Spanish in Ely's original LCR scale was changed to English in the instrument used for the present study, as done in Liu and Jackson's (2008) study. Having five descriptors ranging from 'Strongly Disagree' to 'Strongly Agree' with values 1 to 5 assigned to them respectively, the LCR has a possible score range of 6 to 30 (see Appendix 1-6).

Language Class Sociability Scale (LCS). The original LCS measure, a 5-item scale designed by Ely (1986), indexes the extent to which learners enjoy interacting with others in class in the target language. Like the LCR scale, the word Spanish in the original LCS items was replaced by the word English. To better fit the present research, which observed a variety of activities such as pair work, group work and presentations in the lessons studied, the original LCS item, 'I'd like more class activities where the students use Spanish to get to know each 
Journal of Second Language Teaching and Research Volume One Issue One

other better', as done in Liu and Jackson's (2008) study. Having five alternatives ranging from 'Strongly Disagree' to 'Strongly Agree' with values 1 to 5 assigned to them respectively, the LCS has a possible score range of 4 to 20 (see Appendix 7-10).

Preliminary statistical analyses revealed high internal consistency for the measures (see Table 1). 
Table 1: Characteristics of the instruments $(N=934)$

\begin{tabular}{|c|c|c|c|}
\hline Name of the instrument & No. of items & Reliability & Mean item-total correlation $(p=.01)$ \\
\hline $\mathrm{P}$ & 12 & .48 & .45 \\
\hline $\mathrm{E}$ & 12 & .78 & .76 \\
\hline $\mathrm{N}$ & 12 & .77 & .61 \\
\hline $\mathrm{L}$ & 12 & .63 & .16 \\
\hline RSES & 10 & .34 & .43 \\
\hline LCR & 6 & .614 & .45 \\
\hline LCS & 4 & .635 & \\
\hline
\end{tabular}

Notes: $\mathrm{P}=$ psychoticism; $\mathrm{E}=$ extroversion; $\mathrm{N}=$ neuroticism; $\mathrm{L}=$ lie; $\mathrm{RSES}=$ Rosenberg Self Esteem Scale; LCR = Language Class Risk-Taking Scale; LCS = Language Class Sociability Scale

The background questionnaire. The background questionnaire aimed to gather the respondents' demographic information such as name, gender, department, university, and English-learning time.

Performance in English. All the participants' scores in the mid-term exam administered during the ninth week of the term were collected as their performance in English (Aida, 1994; Liu, 2006). The test consisted of listening, reading, and writing, but excluded speaking in that it was more challenging and time-consuming to administer. In the present study, only the total score was used for statistical analysis.

\section{Procedure}

30 intact classes at three universities answered the survey in 15 minutes during a normal class session of the eighth week of the first 16-week term of the academic year 2007-2008. 
Of 1121 collected questionnaires, 934 were complete for statistical analyses (others were discarded because of incompleteness). In the following week, the students took the mid-term exam of the course which was used as a measure of their performance in English.

\section{Data analysis}

For each measure, the mean, standard deviation, median, mode, maximum, minimum, skewness and kurtosis were calculated to determine the profiles of the students' personality traits, self-esteem, language class risk-taking and sociability. Then, relationships between these measured scales and the students' performance in English were investigated in terms of correlation analyses and regression analyses.

\section{Results and discussions}

\section{Profiles of the students' personality traits, self-esteem, language class risk-taking and sociability}

To describe the profiles of the participants' personality characteristics, self-esteem, language class risk-taking and sociability, the means, standard deviations, medians, modes, ranges, skewnesses and kurtoses of the four scales of the EPQ, the two dimensions of the RSES, the LCR, and the LCS were computed. When doing so, the researchers adjusted the values assigned to the alternatives of some items, as specified in Eysenck et al. (1985), Rosenberg (1965), and Ely (1986). Thus, the higher the SES score, the higher self-esteem the respondent reported to have; the higher the PSE score, the higher positive self-esteem; the higher the NSE score, the lower negative self-esteem. The higher the LCR or the LCS score, the more risk-taking or sociable the respondent was in English classrooms.

Since the LCR consists of 6 items, a total score of more than 24,18 to 24 , and less than 18 on the scale implies that the respondent is highly, moderately, and low risk-taking in English classrooms respectively. Likewise, a total score of more than 16, 12 to 16, and below 12 on the 4-item LCS represents high, moderate, and low sociability in English class respectively. The results are summarized in Table 2. 
Table 2: Personality traits of the participants $(N=934)$

\begin{tabular}{|c|c|c|c|c|c|c|c|}
\hline & Mean & Standard deviation & Median & Mode & Range & Skewness & Kurtosis \\
\hline $\mathrm{P}$ & 14.56 & 1.80 & 14 & 14 & $12-22$ & .769 & .510 \\
\hline $\mathrm{E}$ & 18.97 & 3.08 & 19 & 19 & $12-24$ & -.214 & -.806 \\
\hline $\mathrm{N}$ & 18.15 & 3.04 & 18 & 20 & $12-24$ & -.094 & -.846 \\
\hline $\mathrm{L}$ & 17.69 & 2.36 & 18 & 18 & $12-24$ & .126 & -.455 \\
\hline SES & 26.74 & 2.73 & 27 & 26 & $18-36$ & -.149 & .426 \\
\hline PSE & 14.13 & 1.71 & 14 & 14 & $5-20$ & -.078 & 1.61 \\
\hline NSE & 12.6 & 2.01 & 13 & 13 & $5-20$ & -.333 & .949 \\
\hline LCR & 16.40 & 3.72 & 16 & 16 & $6-30$ & .269 & -.023 \\
\hline LCS & 13.09 & 2.82 & 13 & 12 & $4-20$ & -.091 & .085 \\
\hline
\end{tabular}

Notes: $\mathrm{P}=$ psychoticism; $\mathrm{E}$ = extroversion; $\mathrm{N}$ = neuroticism; $\mathrm{L}=$ lie; $\mathrm{RSES}=$ Rosenberg Self Esteem Scale; PSE = positive self-esteem; NSE = negative self-esteem;

LCR = Language Class Risk-Taking Scale; Language Class Sociability Scale

As noted in Table 2, the actual score range for $E, N$, and $L$ was 12 to 24 , while that for $P$ was 12 to 22. The mean scores for the four scales were $14.56(S D=1.8), 18.97(S D=3.08)$, $18.15(S D=18.15)$, and $17.69(S D=2.36)$ respectively, all of which were near the scale midpoint 18, except the $\mathrm{P}$ mean. And a normal distribution was observed for each scale, as supported by the skewness and kurtosis scores presented in Table 2. All these suggest that most participants were high on $E, N$ and $L$, but moderate or even low on $P$, as found in Eysenck et al.'s (1985) study. Namely, the majority of the respondents were moderately extroverted, moderately inclined to anxiety and fears, and moderately prone to be influenced by social desirability. Meanwhile, the majority reported to be dependent and tender-minded. This might be due to the fact that more than $90 \%$ of this generation were the only child in their family who were normally treated as princes or princesses as a result of the family planning policy executed since early 1970s in China. 
As Table 2 shows, the RSES had an actual score range of 18 to 36 , with a mean of 26.74 $(S D=2.73)$, a median of 27 and a mode of 26 , all slightly exceeding the scale midpoint 25 . The skewness and kurtosis scores implied a normal distribution for the RSES. All these imply that the participants had moderate but not high self-esteem for themselves.

Meanwhile, a mean of 14.13 (SD =1.71), a median and mode of 14 on PSE, all exceeding the scale midpoint 12.5, suggest that the respondents generally had (fairly) high positive views toward themselves. Likewise, a mean of $12.6(S D=2.01)$, a median and mode of 13 on NSE, all slightly above the scale midpoint 12.5 , indicate that more than half the students generally did not hold low self-esteem. And a normal distribution occurred for both PSE and NSE, as evidenced by their skewness and kurtosis values which rarely exceeded 1 . All these results clearly suggest that the participants tended to feel worthy and proud of themselves, as found by Suo and Suo (2007). Unlike their Japanese counterparts who often reported to have low self-esteem (Brown, 2008), these Chinese participants might have been greatly influenced by the predominant philosophical idea long held by the Chinese that 'I am born to be useful' (Feng, 2004).

Table 2 also shows that the LCR had an actual score range of 6 to 30, with a mean of 16.40

$(S D=3.72$ ), a median and mode of 16 , which fell below the scale midpoint 18 . This indicates that the majority of the participants were only moderately or even not risktaking in English class. Likewise, the actual LCS score range in the present study was 4 to 20 , with a mean of 13.09 (SD = 2.82), a median of 13 and a mode of 12 , which slightly exceeded the scale midpoint 12 , implying that the participants were moderately or even strongly sociable in English classrooms. Consistent with those revealed in Liu and Jackson's (2008) study of a sample with similar backgrounds, these findings are further confirmed by the skewness and kurtosis values which were generally far below 1 , denoting the occurrence of a normal distribution for both scales.

\section{Correlations among the measured variables and the students' performance in English}

Correlational analyses revealed the relationships between the measured variables and the students' performance in English (see Table 3). 
Table 3: Correlations between the measured variables and the students' performance in English ( $N=934)$

\begin{tabular}{|c|c|c|c|c|c|c|c|c|c|}
\hline $\begin{array}{c}\text { Variabl } \\
\text { es }\end{array}$ & $E$ & $\mathrm{~N}$ & $L$ & RSES & PSE & NSE & LCR & LCS & $\begin{array}{c}\text { Performan } \\
\text { ce }\end{array}$ \\
\hline$P$ & -.047 & .041 & $-.084^{*}$ & -.025 & -.035 & -.003 & $.076^{\star}$ & $-.082^{*}$ & $-.116^{\star \star}$ \\
\hline$E$ & 1 & $-.221^{* \star}$ & .033 & $.357^{\star \star}$ & $\begin{array}{c}.236^{*} \\
*\end{array}$ & $.285^{\star *}$ & $.222^{\star \star}$ & $.287^{* *}$ & .062 \\
\hline $\mathrm{N}$ & & 1 & $-.233^{\star *}$ & $-.305^{\star *}$ & $\begin{array}{c} \\
.113^{*} \\
*\end{array}$ & $\begin{array}{c}- \\
.320^{* *}\end{array}$ & $-.147^{* *}$ & $-.142^{\star \star}$ & $-.073^{\star}$ \\
\hline$L$ & & & 1 & $.071^{*}$ & .008 & $.090^{*}$ & .005 & .042 & -.049 \\
\hline RSES & & & & 1 & $\begin{array}{c}.681^{*} \\
*\end{array}$ & $.781^{\text {** }}$ & $.208^{\star \star}$ & $.179^{* *}$ & $.181^{* *}$ \\
\hline PSE & & & & & 1 & $.074^{\star}$ & $.110^{* *}$ & $.191^{\star \star}$ & $.172^{\star \star}$ \\
\hline NSE & & & & & & 1 & $.188^{\star *}$ & $.082^{*}$ & $.101^{* *}$ \\
\hline LCR & & & & & & & 1 & $.226^{\star *}$ & $.168^{\star \star}$ \\
\hline LCS & & & & & & & & 1 & $.160^{\star *}$ \\
\hline
\end{tabular}

Note: ${ }^{\star \star}=p<.01 ;{ }^{*}=p<.05$ 
As Table 3 shows, among the correlations between the personality subscales and the RSES and its two subscales, the RSES significantly negatively correlated with $\mathrm{N}(r=-.305, \mathrm{p}<.01)$ but positively with $\mathrm{E}(r=.357, \mathrm{p}<.01)$ and $\mathrm{L}(r=.071, \mathrm{p}<.05)$. It was the same with PSE $(r$ $=-.113$ and .236 for $\mathrm{N}$ and $\mathrm{E}$ respectively, $\mathrm{p}<.01$ ). Likewise, NSE was significantly negatively related to $\mathrm{N}(r=-.320, \mathrm{p}<.01)$ while significantly positively related to $\mathrm{E}(r=.285$, $\mathrm{p}<.01)$ and $\mathrm{L}(r=.090, \mathrm{p}<.05)$. In other words, a respondent who reported to have greater self-esteem, higher positive self-esteem, or lower negative self-esteem tended to be less inclined to anxiety and fears $(N)$, but more extroverted $(E)$ and easier to be influenced by others, as found in previous studies (Dalgas-Pelish, 2006; Pepi et al., 2006; Situ \& Li, 2007; Stringer \& Heath, 2008; Wray \& Stone, 2005).

The RSES and its two subscales were also significantly positively correlated with the LCR ( $r$ $=.208, .110$, and .188 , for the RSES, PSE and NSE respectively, $\mathrm{p}<.01)$ and the LCS $(r=$ $.179, .191$, and .082 , for the RSES, PSE and NSE respectively, $\mathrm{p}<.05)$. This clearly suggests that a person with greater self-esteem, greater positive self-esteem, or lower negative self-esteem tended to be more risk-taking and sociable in English classrooms.

Meanwhile, the LCR was significantly positively related to $\mathrm{P}(r=.076, \mathrm{p}<.05)$ and $\mathrm{E}(r=$ $.222, \mathrm{p}<.01)$, but negatively to $\mathrm{N}(r=-.147, \mathrm{p}<.01)$, and the LCS was significantly positively correlated with $\mathrm{E}(r=.287, \mathrm{p}<.01)$, but negatively with $\mathrm{P}(r=-.082, \mathrm{p}<.05)$ and $\mathrm{N}$ $(r=-.142, \mathrm{p}<.01)$. Alternatively, the respondent who was more tough-minded or more aggressive (higher on $\mathrm{P}$ ) was prone to be more risk-taking but less sociable in English class; the student who was more extroverted (higher on E) was likely to be more risk-taking and more sociable in English classrooms; and the participant who reported to be more inclined to anxiety and fears (higher on $\mathrm{N}$ ) tended to be less risk-taking and less sociable in the class. At the same time, the $L$ (Lie) scale was merely insignificantly positively related to the LCR and the LCS.

Further, the LCR and the LCS were significantly positively correlated with each other $(r=$ $.226, p<.01)$. Namely, a more risk-taking student tended to be more sociable in English class. 
Finally, among the four EPQ scales, only $\mathrm{P}$ and $\mathrm{N}$ were significantly but negatively related to the students' performance in English $(r=-.116$ and -.073 for $P$ and $N$ respectively, $p<.05)$. All the RSES scales, the LCS, and the LCR were all significantly positively correlated with the latter, with coefficients ranging from .101 to .181 $(p<.01)$. This further supports numerous existing studies (Hwu, 2007; Robinson et al., 1994; Verhoeven \& Vermeer, 2002; Wakamoto, 2000). That is, an individual who reported to be more tough-minded (higher on $\mathrm{P}$ ) or more inclined to fears and anxiety (higher on $\mathrm{N}$ ) tended to perform worse in the midterm exam. Conversely, a student who reported to have greater global self-esteem, higher positive self-esteem, or lower negative self-esteem tended to score higher in the test; so did a student who reported to be more risk-taking and/or more sociable in English class.

As such, it is clear that the students' personality characteristics, self-esteem, language class risk-taking and sociability were closely related to one another and might work together to affect the students' performance in English.

\section{The regression model}

The results of the correlational analyses discussed previously show numerous bivariate relationships, which failed to indicate the influence of one variable on another. Better clues were provided by multiple regression analyses. A stepwise method was employed in forming regression models, with performance in English being the dependent variable and the other variables as independent ones. Altogether five models were resulted with the change in $R^{2}$ being all significant: .033 for model 1 (RSES, $p=.000$ ), .018 for model 2 (RSES, LCR, $p=$ .000), .015 for model 3 (RSES, LCR, P, p = .000), .009 for model 4 (RSES, LCR, P, LCS, $p$ $=.004$ ), and .005 for model 5 (RSES, LCR, P, LCS, L, $p=.026$ ). Table 4 reports coefficients from the regression models, as well as their levels of significance. 
Table 4: Regression coefficients and significance

\begin{tabular}{|c|c|c|c|c|c|c|}
\hline \multicolumn{2}{|c|}{} & RSES & LCR & P & LCS & L \\
\hline $\begin{array}{c}\text { Performance } \\
\text { in English }\end{array}$ & $\beta$ & .138 & .125 & -.120 & .099 & -.071 \\
\cline { 2 - 7 } & $t$ & 4.199 & 3.759 & -3.716 & 2.977 & -2.223 \\
\cline { 2 - 7 } & $\mathrm{p}$ & .000 & .000 & .000 & .003 & .026 \\
\cline { 2 - 7 } & VIF & 1.072 & 1.095 & 1.021 & 1.089 & 1.010 \\
\hline
\end{tabular}

As can be seen, all the coefficients were statistically significant at the .000 level except the LCS $(p=.003)$ and $L(p=.013)$. Among the five included variables, the RSES was the most powerful predictor $(\beta=.138, t=4.199)$, followed by the LCR $(\beta=.125, t=3.759), \mathrm{P}(\beta=-$ $.120, t=-3.716)$, the LCS $(\beta=.099, t=2.977)$, and $\mathrm{L}(\beta=-.071, t=-2.223)$. The RSES, the LCR, and the LCS were positive predictors, while $P$ and $L$ were negative ones. Strangely, when working alone, $L$ was just negatively correlated with the students' performance in English; but when interacting with other variables, it became a powerful predictor for the latter.

Thus, it can be drawn that such individual differences as personality traits, self-esteem, and language class risk-taking and sociability all exerted certain impact on the students' performance in English.

\section{Conclusions and implications}

Several conclusions concerning students' personality traits, self-esteem, language class risktaking and sociability, and their performance in English in the Chinese EFL context are warranted from the results of this study.

First, analyses of the data revealed that the majority of students were moderately extroverted, moderately inclined to anxiety and fears, and moderately prone to be influenced 
by social desirability but tended to be dependent and tender-minded, that the participants were moderately satisfied with themselves and believed they were good and useful, and that the majority were moderately risk-taking and sociable in English class. Second, correlational analyses indicated that personality traits, self-esteem, language class risk-taking and sociability were generally significantly correlated with one another. For example, a person with higher self-esteem tended to be more risk-taking and sociable in English classrooms. Meanwhile, these variables were generally significantly related to the students' performance in English. Among them, the RSES, the LCR, P, the LCS, and L proved to be powerful predictors for the latter. Clearly, such individual differences as personality traits, self-esteem, language class risk-taking and sociability interacted with one another to yield certain impact on the students' performance in English.

Thus, to better students' performance in English, it is crucial to maintain and raise their selfesteem, especially in a Chinese EFL context where face value is highly held (Bond, 1996; Liu, 2006). Some studies suggest that teachers can help learners develop positive situational self-esteem by assessing their progress realistically (Oxford, 1990) and by discounting the areas in which students do not have peak performance (Harter, 1986). For example, teachers can supervise learners in setting realistic goals during the course of learning a SL/FL, and praise them when the goals are accomplished. Meanwhile, teachers can scaffold topics and activities in terms of familiarity and difficulty to better suit the learners and the context, so that the students may feel (more) assured of themselves in accomplishing the tasks, as suggested in Liu (2006). If a student's self-esteem is enhanced, he/she may become more likely to take risks when using the target language in class and socialize with others as well in the class.

Although personality traits are relatively stable across time, it's highly possible to identify students' personality characteristics, which can help orient them to adopt learning strategies that may be more appropriate to them, as suggested in Oxford and Ehrman's (1995) and Ehrman and Oxford's (1995) studies. With a knowledge of students' personality characteristics, teachers are able to know what kind of students may be more inclined to high self-esteem, class risk-taking and sociability. By offering more help to these students, the teachers may help improve their learning outcomes. This, however, is easier said than done. To really understand individual students' characteristics requires great effort (e.g. 
Journal of Second Language Teaching and Research Volume One Issue One

patience, perseverance and long-time observation, etc.) on the teachers' part and the students' active cooperation.

Finally, since the participants of the present study came from three universities representative of varying ranks of institutions in China, the findings can thus be generalized to other EFL contexts in the country. Even so, it should be noted that the present study did not take such variables as gender, discipline and proficiency into consideration, an exploration of which shall be interesting and thus can be the focus of future studies. 


\section{References}

Aida, Y. (1994). Examination of Horwitz, Horwitz, and Cope's construct of foreign language anxiety: The case of students of Japanese. The Modern Language Journal, 78, pp.155168.

Baker, S. C., \& Maclntyre, P. D. (2000). The role of gender and immersion in communication and second language orientations. Language Learning, 50, pp.311-341.

Bond, M. H. (1996). The handbook of Chinese psychology. Oxford: Oxford University Press.

Brown, D. (1987) Principles of language learning and language teaching. Englewood Cliffs: Printice Hall.

Brown, R. A. (2008). Censure avoidance and self-esteem. The Journal of Social Psychology, 148, pp.653-666.

Busch, D. (1982). Introversion-extroversion and the EFL proficiency of Japanese students. Language Learning, 32, pp.109-132.

Cameron, L. J. (1990). Staying within the script: personality and self-directed learning. System, 18, pp.65-75.

Carrell, P. L., Prince, M. S., \& Astika, G. G. (1996). Personality types and language learning in an EFL context. Language Learning, 46, pp.75-99.

Coopersmith, S. (1981). Self-esteem inventories. Palo Alto, CA: Consulting Psychologists Press, Inc.

Cortazzi, M., \& Jin, L. (1996). Cultures of learning: language classrooms in China. In H. Coleman (ed.), Society and the language classroom (pp. 169-206). Cambridge: Cambridge University Press.

Dalgas-Pelish, P. (2006). Effects of a self-esteem intervention program on school-age children. Pediatric Nursing, 32, pp.341-348.

Ehrman, M. E., \& Oxford, R. L. (1990). Adult language learning styles and strategies in an intensive training setting. The Modern Language Journal, 74, pp.311-327.

Ehrman, M. E., \& Oxford, R. L. (1995). Cognition plus: correlates of language learning success. The Modern Language Journal, 79, pp.67-89. 
Ely, C. M. (1986). An analysis of discomfort, risk-taking, sociability, and motivation in the L2 classroom. Language Learning, 36, pp.1-25.

Eysenck, H. J., \& Eysenck, S. B. G. (1975). Manual of the Esysenck personality questionnaire. London: Hodder \& Stoughton.

Eysenck, M. W. (1974). Extraversion, arousal and retrieval from semantic memory. Journal of Personality, 42, pp.319-331.

Eysenck, M. W., \& Eysenck, M. (1979). Memory scanning, introversion-extraversion and levels of processing. Journal of Research in Personality, 13, pp.305-315.

Eysenck, S. B. G., Eysenck, H. J., \& Barrett, P. (1985). A revised version of the psychoticism scale. Personality and Individual Differences, 6, pp.21-29.

Feng, Y-L. (2004). A history of Chinese philosophy (New Edition). Beijing: People's Press.

Flowerdew, J., Miller L., \& Li, D. C. S. (2000). Chinese lecturers' perceptions, problems and strategies in lecturing in English to Chinese-speaking students. RELC Journal, 31, pp.116-138.

Foust, M. A. (2007). William James and the promise of pragmatics. Retrieved on Sep. 7, 2009 from http://williamjamesstudies.press.illinois.edu/2.1/foust.html.

Gardner, R. C., Tremblay, P. F., \& Masgoret, A. M. (1997). Towards a full model of secondlanguage learning: An empirical investigation. The Modern Language Journal, 81, p.344362.

Harter, S. (1986). Feeling good about yourself isn't enough. Psychology Today, 8, pp.2-3.

Hashimoto, Y. (2002). Motivation and willingness to communicate as predictors of reported L2 use: the Japanese ESL context. Second Language Studies, 20, pp.29-70.

Hurd, S. (2006). Towards a better understanding of the dynamic role of the distance language learner: learner perceptions of personality, motivation, roles, and approaches. Distance Education, 27, pp.303-329.

Hwu, F. (2007). Learners' strategies with a grammar application: The influence of language ability and personality preferences. ReCALL, 19, pp.21-38. 
Ja, R., Huai, L-L., \& Guo, W. (2007). 初中生成就动机与自尊的相关研究 (The relationship between achievement-motivation and self-esteem of junior high school students). China Journal of Health Psychology, 15, pp.642-644.

Jackson, J. (2002). Reticence in second language case discussions: anxiety and aspirations. System, 30, pp.65-84.

Kiany, G. R. (1997). Personality and language learning: the contradiction between psychologists and applied linguists. ITL: Review of Applied Linguistics, pp.115-116, pp.111-136.

Krupa-Kwiatkowski, M. (1998). 'You shouldn't have brought me here!': interaction strategies in the silent period of an inner-direct second language learner. Research on Language and Social Interaction, 31, pp.133-175.

Littlewood, W. (2000). Do Asian learners really want to listen and obey? ELT, 45(1), pp.3136.

Liu, M. (2006). Reticence in oral English classrooms: causes and consequences. Asian Journal of English Language Teaching, 16, pp.45-66.

Liu, M., \& Jackson, J. (2008). An exploration of Chinese EFL learners' unwillingness to communicate and foreign language anxiety. The Modern Language Journal, 92, pp.7186.

Liu, M., \& Jackson, J. (2009). Reticence in Chinese EFL students with varied proficiency levels. TESL Canada Journal, 26, pp.65-81.

Liu, M, \& Jackson, J. (2011). Reticence and anxiety in oral English lessons: A case study in Mainland China. In L. Jin \& M. Cortazzi (Eds.), Researching Chinese learners—skills, perceptions, and intercultural adaptation, pp.119-137. Basingstoke, U.K.: Palgrave MacMillan.

Macintyre, P. D., Baker, S. C., Clément, R., \& Donovan, L. A. (2003). Sex and age effects on willingness to communicate, anxiety, perceived competence, and L2 motivation among junior high school French immersion students. Language Learning, 53, pp.137-165. 
MacIntyre, P. D., \& Charos, C. (1996). Personality, attitudes, and affect as predictors of second language communication. Journal of Language and Social Psychology, 15, pp.326.

McCaulley, M. H., \& Natter, F. (1974). Psychological (Myres-Briggs) type differences in education. Gainesville, FL: Center for Applications of Psychological Type.

Myres, I. B., \& Myres, P. B. (1980). Gifts differing. Palo Alto: Consulting Psychologists.

Oxford, R. L. (1990). Language learning strategies: what every teacher should know. New York: Newbury House/Harper \& Row. Now Boston: Heinle \& Heinle.

Oxford, R. L., \& Ehrman, M. (1995). Adults' language learning strategies in an intensive foreign language program in the United States. System, 23, pp.359-386.

Pepi, A., Faria, L., \& Alesi, M. (2006). Personal conceptions of intelligence, self-esteem, and school achievement. Adolescence, 41, pp.615-631.

Pierce, C. (1994). Importance of classroom climate for at-risk learners. Journal of Educational Research, 88, pp.37-42

Rayle, A. D., Arredondo, P., \& Kurpius, S. E. R. (2005). Educational self-efficacy of college women: implications for theory, research and practice. Journal of Counseling and Development: JCD, 83, pp.361-366.

Riding, R. J., \& Banner, G. E. (1986). Sex and personality differences in second language performance in secondary school pupils. The British Journal of Educational Psychology, 56, pp.366-370.

Robinson, D., Gabriel, N., \& Katchan, O. (1994). Personality and second language learning. Personality and Individual Differences, 16, pp.143-157.

Rogers, C. R., \& Dymond, R. F. (Eds.). (1954). Psychotherapy and personality change: coordinated studies in the client-centered approach. Chicago: University of Chicago Press.

Rosenberg, M. (1965). Society and the adolescent self-Image. Princeton, N.J.: Princeton University Press.

Saito, H., \& Ebsworth, M. E. (2004). Seeing English language teaching and learning through the eyes of Japanese EFL and ESL students. Foreign Language Annals, 37, pp.111-124.

Situ, Q-M., \& Li, J-B. (2007). 大学新生自尊与社交焦虑的关系 (Relationship between selfesteem and interactive anxiety). China Journal of Health Psychology, 15, pp.1005-1007. 
Journal of Second Language Teaching and Research Volume One Issue One

Skehan, P. (1989). Individual differences in second language learning. New York: Edward Arnold.

Spada, N. (1986). The interaction between types of contact and types on instruction: some effects on the second language proficiency of adult learners. SSLA, pp.181-199.

Stringer, R. W., \& Heath, N. (2008). Academic self-perception and its relationship to academic performance. Canadian Journal of Education, 31, pp.327-345.

Suo, S., \& Suo, B. (2007). 硕士研究生自尊状况的调查研究 (A study of graduates' selfesteem). Journal of Xinzhou Teachers' University, 23, pp.90-92.

Swain, M. (1985). Communicative competence: some roles of comprehensible input and comprehensible output in its development. In S. M. Gass \& C. G. Madden (Eds.), Input in second language acquisition (pp.235-253). Rowley, MA: Knobbier House.

Tsou, W. (2005). Improving speaking skills through instruction in oral classroom participation. Foreign Language Annals, 38, pp.46-55.

Tsui, A. B. M., (1996). Reticence and anxiety in second language learning. In K. M. Bailey, \& D. Nunan (Eds.), Voices from the language classroom (pp. 145-167). Cambridge, England: Cambridge University Press.

Verhoeven, L., \& Vermeer, A. (2002). Communicative competence and personality dimensions in first and second language learners. Applied Psycholinguistics, 23, pp.361374.

Wakamoto, N. (2000). Language learning strategy and personality variables: focusing on extroversion and introversion. IRAL, 38, pp.71-81.

Watkins, D. (2000). Learning and teaching: a cross-cultural perspective. School leadership \& Management, 20, pp.161-173.

Wilson, R.G., \& Lynn, R. (1990). Personality, intelligence components and foreign language attainment. Educational Psychology, 10, pp.57-71.

Wray, L. D., \& Stone, E. R. (2005). The role of self-esteem and anxiety in decision making for self versus others in relationships. Journal of Behavioral Decision Making, 18, pp.125144.

Yashima, T. (2002). Willingness to communicate in a second language: the Japanese EFL context. The Modern Language Journal, 86, pp.54-66. 
Journal of Second Language Teaching and Research Volume One Issue One

Yashima, T., Zenuk-Nishide, L., \& Shimizu, K. (2004). The influence of attitudes and affect on willingness to communicate and second language communication. Language Learning, 54, pp.119-152.

Zhang, L. (2005). Prediction of Chinese life satisfaction: contribution of collective selfesteem. International Journal of Psychology, 40, pp.189-200.

Zhang, W., \& Liu, M. (2008). Investigating cognitive and metacognitive strategy use during an English proficiency test. Indonesian Journal of English Language Teaching, 2, pp.122-139.

Zou, M. (2004). EFL learners' perceptions of in-class relationships and their voluntary responses. In Y. Gao (Ed.), The social psychology of English learning by Chinese college students (pp.149-167). Beijing: Foreign Language Teaching and Research Press.

\section{Biodata}

Meihua Liu, PhD, is Associate Professor of English at the Department of Foreign Languages \& Literatures, Tsinghua University, China. Her research interests mainly include second/foreign language teaching and learning, individual differences, reticence and anxiety, and second language writing. 


\section{Appendix: The survey}

Direction: This survey aims to help better understand individual differences and their roles in English learning. Please answer the following items by circling the letter of the alternative which appears most applicable to you. We would urge you to be as accurate as possible since the success of this investigation depends upon it. All the data produced will be used only for research.

\begin{tabular}{|c|c|c|c|c|c|}
\hline $\begin{array}{l}\text { 1. I like to wait until I know exactly how to use an English word before } \\
\text { using it. }\end{array}$ & 1 & 2 & 3 & 4 & 5 \\
\hline 2. I don't like trying out a difficult sentence in class. & 1 & 2 & 3 & 4 & 5 \\
\hline $\begin{array}{l}\text { 3. At this point, I don't like trying to express complicated ideas in English } \\
\text { in class. }\end{array}$ & 1 & 2 & 3 & 4 & 5 \\
\hline $\begin{array}{l}\text { 4. I prefer to say what I want in English without worrying about the small } \\
\text { details of grammar. }\end{array}$ & 1 & 2 & 3 & 4 & 5 \\
\hline 5. In class, I prefer to say a sentence to myself before I speak it. & 1 & 2 & 3 & 4 & 5 \\
\hline $\begin{array}{l}\text { 6. I prefer to follow basic sentence models rather than risk misusing the } \\
\text { language. }\end{array}$ & 1 & 2 & 3 & 4 & 5 \\
\hline $\begin{array}{l}\text { 7. I think learning English in a group is more fun than learning on my } \\
\text { own. }\end{array}$ & 1 & 2 & 3 & 4 & 5 \\
\hline 8. I enjoy talking with the teacher and other students in English. & 1 & 2 & 3 & 4 & 5 \\
\hline 9. I enjoy interacting with the other students in the English class. & 1 & 2 & 3 & 4 & 5 \\
\hline $\begin{array}{l}\text { 10. I think it's important to have a strong group spirit in the English } \\
\text { classroom. }\end{array}$ & 1 & 2 & 3 & 4 & 5 \\
\hline 11. On the whole, I am satisfied with myself. & 1 & 2 & 3 & 4 & \\
\hline 12. At times, I think I am no good at all. & 1 & 2 & 3 & 4 & \\
\hline 13. I feel that I have a number of good qualities. & 1 & 2 & 3 & 4 & \\
\hline
\end{tabular}




\begin{tabular}{|c|c|c|c|c|}
\hline 14. I am able to do things as well as most other people. & 1 & 2 & 3 & 4 \\
\hline 15. I feel I do not have much to be proud of. & 1 & 2 & 3 & 4 \\
\hline 16. I certainly feel useless at times. & 1 & 2 & 3 & 4 \\
\hline $\begin{array}{l}\text { 17. I feel that I'm a person of worth, at least on an equal plane with } \\
\text { others. }\end{array}$ & 1 & 2 & 3 & 4 \\
\hline 18. I wish I could have more respect for myself. & 1 & 2 & 3 & 4 \\
\hline 19. All in all, I am inclined to feel that I am a failure. & 1 & 2 & 3 & 4 \\
\hline 20. I take a positive attitude toward myself. & 1 & 2 & 3 & 4 \\
\hline 21. Does your mood often go up and down? & 1 & 2 & & \\
\hline 22. Do you take much notice of what people think? & 1 & 2 & & \\
\hline 23. Are you a talkative person? & 1 & 2 & & \\
\hline $\begin{array}{l}\text { 24. If you say you will do something, do you always keep your promise } \\
\text { no matter how inconvenient it might be? }\end{array}$ & 1 & 2 & & \\
\hline 25. Do you ever feel 'just miserable' for no reason? & 1 & 2 & & \\
\hline 26. Would being in debt worry you? & 1 & 2 & & \\
\hline 27. Are you rather lively? & 1 & 2 & & \\
\hline $\begin{array}{l}\text { 28. Were you ever greedy by helping yourself to more than your share of } \\
\text { anything? }\end{array}$ & 1 & 2 & & \\
\hline 29. Are you an irritable person? & 1 & 2 & & \\
\hline $\begin{array}{l}\text { 30. Would you take drugs which may have strange or dangerous } \\
\text { effects? }\end{array}$ & 1 & 2 & & \\
\hline 31. Do you enjoy meeting new people? & 1 & 2 & & \\
\hline $\begin{array}{l}\text { 32. Have you ever blamed someone for doing something you knew was } \\
\text { really your fault? }\end{array}$ & 1 & 2 & & \\
\hline
\end{tabular}




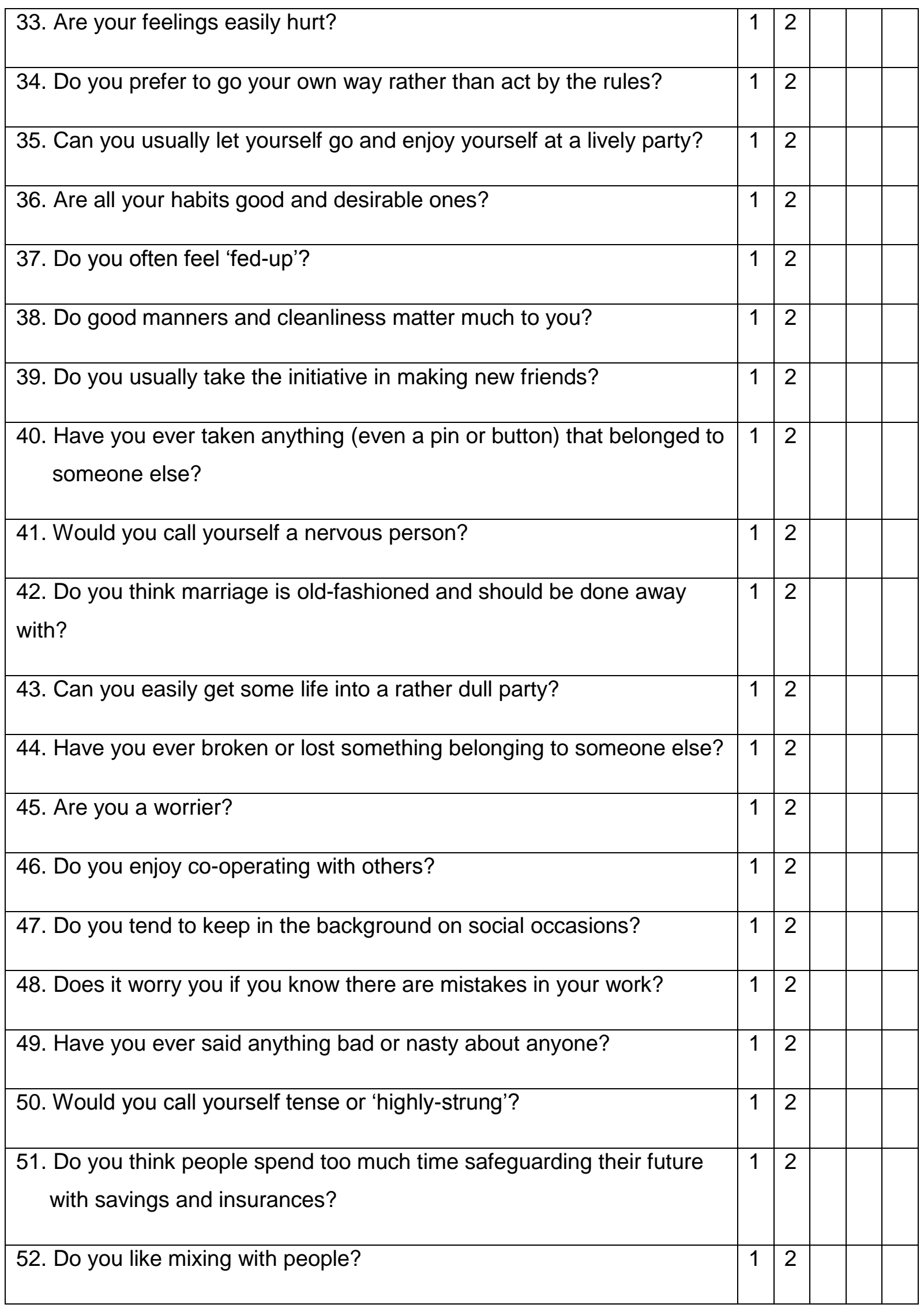




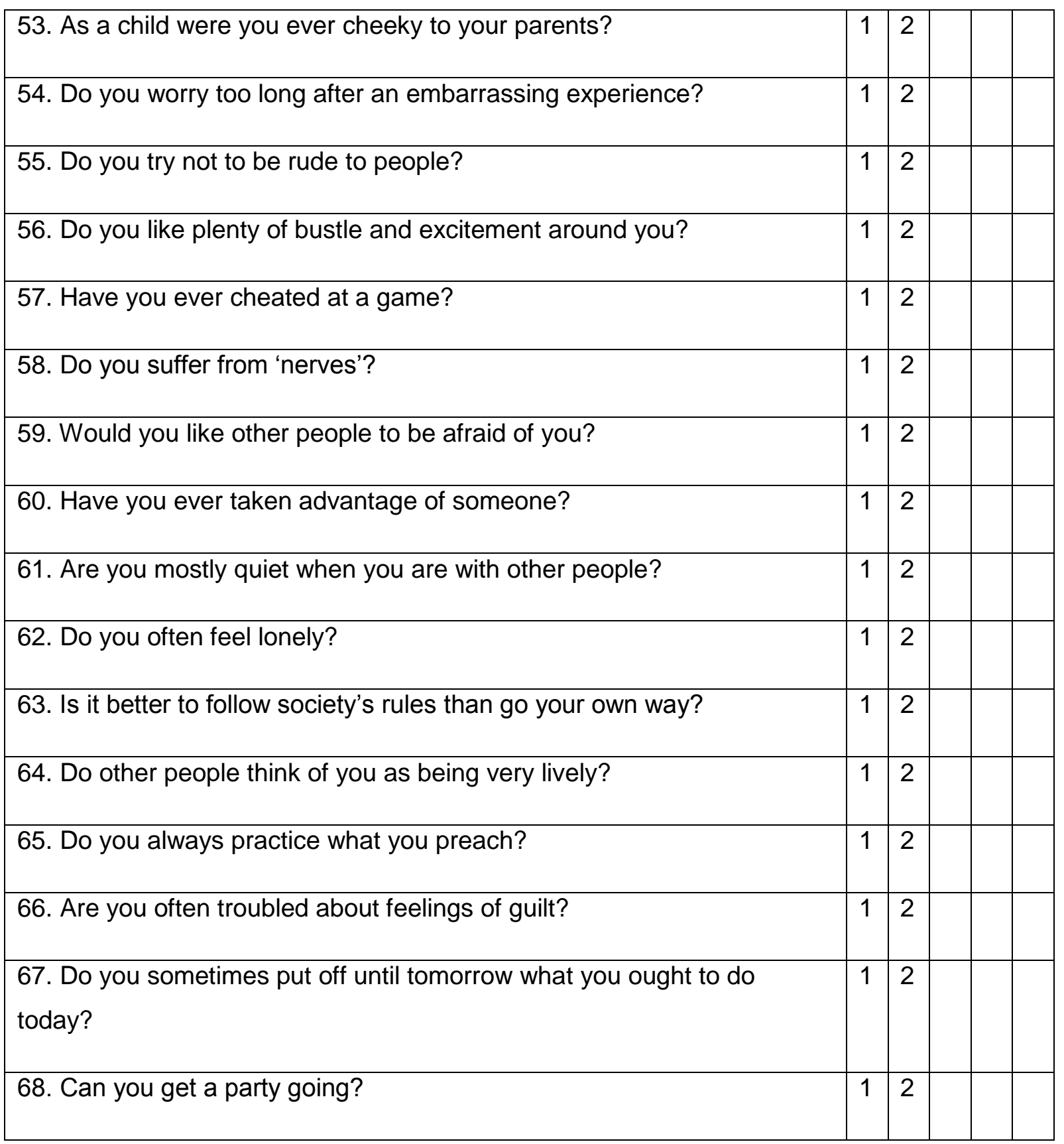

